\title{
MENINGKATKAN KEMAMPUAN KOGNITIF PENGENALAN HURUF MELALUI MEDIA KARTU HURUF PADA KELOMPOK B KB ANGGREK MUARA BADAK TAHUN AJARAN 2015/2016
}

\author{
Masna \\ PG PAUD, FKIP, Universitas Widya Gama Mahakam Samarinda \\ masnapaud15@gmail.com
}

\begin{abstract}
To improve students' cognitive, most educational institutions always prioritize IQ intellectual intelligence only when creativity is important. This study aims to determine whether the media card letters can improve the cognitive abilities of children group B play group Anggrek Muara Badak year Teaching 2015/2016 or not. Research subjects in this study were children Anggrek play group A Muara Badak which amounted to sixteen children, consisting of nine boys and seven daughters. This research is a classroom action research. This research was conducted in two cycles, namely cycle one and Cycle two, with each stage, that is planning, implementation, observation, and reflection. Data collection techniques used are observations in the form of teacher and student observation sheets, and documentation, Data analysis methods used descriptive analysis with qualitative approach. Classroom Action Research is conducted collaboratively with peers, researchers here act as teachers and peers acting as observers or observers. From the results of the discussion can be concluded that the cartuhuruf media of cardboard can improve the cognitive abilities of children in group B children in play group Anggrek Muara Badak Year Teaching 2015/2016. Can improve. This can be seen in the percentage increase that occurs the average completeness of the achievement of the letters of children recognition achieving the indicator of Excellent Growth before the action is $0.00 \%$ to $40.63 \%$ in cycle one and after some improvement in cycle two reached $79.67 \%$ or twelve children out of six twelve children have reached the Very Good Growing indicator. (2) The teacher gives positive reinforcement to the child, (3) The teacher or researcher teaches by giving praise orally so that children are motivated and feel appreciated. From this research, it can be concluded that the use of letter card media can improve cognitive ability of group B children playing Anggrek Muara Badak in academic year 2015/2016. For that reason that in improving cognitive abilities of children, teachers are advised to use the letter card media.
\end{abstract}

Keywords : Cognitive Ability, letter recognition, Media.

\section{PENDAHULUAN}

Kelompok Bermain yang di singkat
dengan KB adalah merupakan jalur
pendidikan non formal. Hal ini telah di
jelaskan pada undang-undang sistem
pendidikan nasional nomor 20 tahun 2003
yang telah memberikan payung hukum dalam
menyelesaikan pendidikan anak usia dini
pada jalur pendidikan. Pasal 28 menegaskan

tentang penyelenggaraan pendidikan anak usia dini pada jalur informal (keluarga), pendidikan nonformal (kelompok bermain dan tempat penitipan anak) dan jalur formal (taman kanak-kanak dan raudatul athfal).

Usia anak KB yang merupakan anak usia dini berkisar 2-6 Tahun, pada masa tersebut anak berkembang secara pesat pada semua aspek perkembangan anak, meliputi 
perkembangan kongnitif, perkembangan bahasa, perkembangan fisik (motorik kasar dan halus) sosial dan emosional.

Kognitif atau intelektual adalah suatu proses berpikir berupa kemampuan atau daya untuk menghubungkan suatu peristiwa dengan peristiwa lainnya serta kemampuan menilai dan mempertimbangkan segala sesuatu yang diamati dari dunia sekitar Beck (1994:15).

Menurut Carol Seefelt dan Barbara A.Wasik (2008:330-331), Bahwa pengertian Kemampuan mengenal huruf adalah kesanggupan melakukan sesuatu dengan mengenali tanda-tanda/cirri-ciri dari tanda aksara dalam tata tulis yang merupakan anggota abjad yang melambangkan bunyi bahasa.

Pendapat Ehri dam Mc.Cormack belajar huruf adalah komponen hakiki dari perkembangan baca tulis.Anak bisa membaca beberapa kata dan mengenal huruf cetak dilingkungan/environmental print sebelum mereka mengetahui abjad.Anak menyebut huruf pada daftar abjad,dalam belajar membaca tidak memiliki kesulitan dari pada anak yang tidak mengenal huruf ( Carol Seefelt Dan Barbara A.Wasik,2008: 331 ).

Pendidikan Kelompok Bermain (KB) merupakan salah satu bentuk pendidikan anak usia dini yang berada pada jalur pendidikan non formal, Seperti yang di maksud dalam Peraturan Pemerintah Nomor 27 tahun 1990. Sebagai lembaga pendidikan prasekolah, Tugas utama kelompok bermain adalah mempersiapkan anak dengan memperkenalkan berbagai pengetahuan, sikap dan perilaku, Serta keterampilan agar anak dapat melanjutkan kegiatan belajar yang sesungguhnya disekolah dasar.

Pembelajaran Pengenalan Huruf di kelompok bermain hendaknya dapat diberikan secara terpadu dalam program pengembangan kemampuan dasar, hal ini bidang pengembangan berbahasa dan motorik.

Kartu kata merupakan salah satu bentuk alat permainan edukatif (APE), yangmenggunakan media kartu. Menurut Suharso dan Ana Retnoningsih (2009: 226), Kartu adalah kertas tebal yang berbentuk persegi panjang, untuk keperluan seperti: tanda anggota, karcis dan lain-lain. Media kartu adalah adalah kartu kecil yang berisi gambar, konsep, soal, atau tanda simbol yang mengingatkan atau menuntun anak kepada sesuatu yang berhubungan dengan materi yang sedang dipelajari. Kartu tersebut biasanya berukuran $8 \times 12 \mathrm{~cm}$ atau dapat disesuaikan dengan besar kecilnya yang dihadapi (Azhar Arsyad, 2006: 119).

Peran guru di kelas dalam penerapan metode permainan kartu huruf dalah membuat siswa dalam meningkatkan kemampuan untuk membaca agar menjadi lebih baik. Guru memberikan pemahaman dan penjelasan kepada para murid terkait permainan karttu huruf yang akan dilaksanakan. Selain itu, guru juga mendampingi dan menuntun siswa dalam pelaksanaan permainan kartu huruf.Tugas 
guru adalah mengelola kelas agar menjadi ruangan bermain dan belajar yang kondusif dan reprensentatif serta menyenangkan.

Melalui permaianan kartu huruf, siswa diajarkan untuk dapat menentukan persamaan dan perbedaan bentuk huruf. Dengan kemampuan yang dimiliki siswa dalam membedakan bentuk masing-masing huruf tersebut, merupakan salah satu keahlian yang dibutuhkan bagi perkembangan membaca anak. Pada masa pertumbuhan, anak-anak terbiasa dengan huruf dan bentuk-bentuk tulisan. Mereka kemudian belajar alpahabet.Anak-anak mengembangkan keterampilan awal membaca dengan mencocokkan, memilah dan membandingan bentuk-bentuk huruf.

Seorang guru juga diharapkan mempunyai kemampuan dalam menggunakan berbagai media pembelajaran uraian diatas, seorang guru diharapkan dapat menggunakan media pembelajaran dengan mahir dan terampil dalam menyampaikan suatu bentuk pembelajaran Pengenalan Huruf terhadap anak didik, Salah satu media yang dapat digunakan adalah kartu huruf. Harapannya, dengan media tersebut proses belajar-mengajar di kelompok bermain Akan lebih hidup dan menyenangkan. Dengan menggunakan media pembelajaran,anak didik akan termotivasi untuk lebih giat lagi dalam belajar dan bermain sehingga anak didik terlibat langsung dalam proses belajar dan bermain.Pembelajaran pada anak usia dini khususnya Kelompok Bermain (KB) merupakan wahana untuk mengembangkan potensi seoptimal mungkin sesuai dengan kemampuan bakat dan minat masing-masing anak. Pendidikan di Kelompok Bermain memberikan kesempatan untuk mengembangkan kepribadian anak,karena itu pendidikan untuk anak perlu menyediakan berbagai kegiatan yang dapat mengembangkan berbagai aspek perkembangan yang meliputi aspek kognitif,afektif dan motorik.

Sistem pembelajaran yang yang berpusat pada anak melalui kelompok, anak didik saling berinteraksi antara satu dengan lainnya sehingga masing-masing anak dapat belajar dengan anak lainnya. Hal ini menggambarkan bahwa peran seorang guru adalah sebagai fasilitator dan motivator.

Kelompok Bermain (KB) didefenisikan sebagai tempat untuk mempersiapkan anakanak memasuki masa sekolah yang dimulai dengan jenjang Sekolah Dasar (SD). Kegiatan yang dilakukan di kelompok bermain pun hanyalah bermain menggunakan alat-alat bermain edukatif. Pelajaran membaca, menulis dan berhitung tidak diperkenalkan ditingkat taman kanak-kanak, kecuali hanya pengenalan huruf-huruf dan angka-angka, Itupun dilakukan setelah anak-anak memasuki TK B.

Guru di KB Anggrek telah mengupayakan pelajaran pengenalan huruf bagi murid muridnya. Metode belajar yang diperatekkan sebatas pengenalan huruf dan mengeja yang 
ditulis pada papan tulis,hasilnya kurang optimal.Anak banyak tidak Fokus dan sibuk dengan kegiatannya sendiri.Karena itu, penulis ingin mempraktekkan metode pengembangan kognitif dalam hal ini mengenai huruf dengan media yang digunakan dalam kegiatan ini adalah "Kartu Huruf". Di harapkan dengan Menggunakan media ini maka anak - anak Akan termotivasi untuk lebih belajar dan bermain sehingga anak didik terlibat langsung dalam proses belajar sambil bermain.

\section{METODOLOGI PENELITIAN}

\section{Desain Penelitian}

Pendekatan penelitian yang digunakan dalam penelitian ini adalah pendekatan deskriptif kuantitatif, dan jenis penelitian ini adalah penelitian tindakan kelas (classroom action research). Menurut Suharsimi Arikunto (2007: 3) "Penelitian tindakan kelas merupakan pencermatan terhadap kegiatan belajar berupa sebuah tindakan yang sengaja dimunculkan dan terjadi dalam sebuah kelas secara bersama".

Tujuan penelitian tindakan kelas adalah memperbaiki proses pembelajaran nyata yang terjadi di kelas, meningkatkan kegiatan nyata guru dalam pengembangan kompetensi profesional, dan memperbaiki berbagai persoalan nyata praktis dalam peningkatan mutu pembelajaran dikelas. Penelitian tindakan yang dilakukan oleh guru sekaligus sebagai peneliti di kelasnya, atau berkolaborasi dengan guru kelas bekerjasama dengan jalan merancang, melaksanakan, dan merefleksi tindakan secara partisipasif dengan tujuan untuk meningkatkan mutu pembelajaran tertentu dalam suatu siklus. Oleh karena itu, dalam penelitian ini yang diutamakan adalah meningkatkan kualitas pembelajaran dengan media yang dianggap tepat untuk meningkatkan kemampuan mengenal huruf menggunakan media kartu kata pada kelompok B.

Sejak dari perencanaan penelitian, peneliti selalu terlibat langsung dalam proses pembelajaran. Peneliti juga memantau, mencatat, mengumpulkan data, menganalisis data dan melaporkan hasil penelitian yang dibantu oleh guru kelas. Guru kelas sebagai kolaborator dalam sebuah penelitian tindakan yang terjadi di kelas dilakukan secara bersama dengan peneliti.

Menurut Suharsimi Arikunto (2006: 93) model penelitian dalam penelitian tindakan kelas ini mengacu pada model penelitian tindakan Kemmis dan Mc Taggart yang menyatakan bahwa model penelitian Kemmis dan Mc Taggart merupakan pengembangan model Kurt Lewin. Model Kurt Lewin memiliki empat komponen yaitu perencanaan (planning), tindakan (acting), pengamatan (observing), dan refleksi (reflecting). Model Kemmis dan Mc Taggart, juga menggunakan keempat komponen penelitian tersebut dalam setiap langkah. Akan tetapi pada model Kemmis dan Mc Taggart, komponen tindakandan pengamatan menjadi satu 
komponen karena kedua kegiatan ini dilakukan secara simultan seperti pada gambar

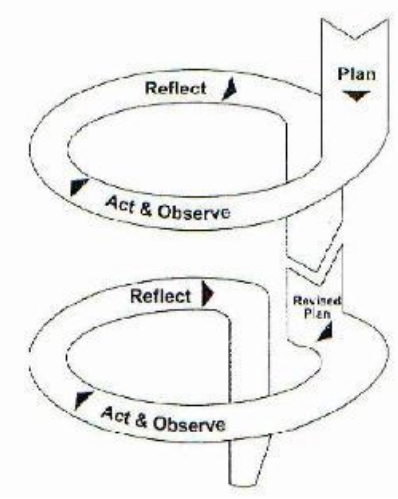

Gambar 1. Proses penelitian Tindakan Kelas

Siklus I: 1. Perencanaan

2. Tindakan dan Observasi

3. Refleksi

Siklus II: 1.Perencanaan Hasil Revisi

2. Tindakan Dan observasi

3. Refleksi

Model Penelitian Tindakan Kelas Kemmis

\& Mc.Taggart (Suharsimi Arikunto, 2006: 93).

\section{Subjek penelitian}

Subjek penelitian adalah anak usia dini anak Meningkatkan Kemampuan Kognitif pengenalan huruf melalui media kartu huruf Pada Kelompok B Kb Anggrek Muara Badak Tahun Ajaran 2015/2016 yang berjumlah 16 anak, terdiri dari 9 anak laki-laki dan 7 anak perempuan. Objek dalam penelitian ini adalah kemampuan Kognitif Anak.

\section{Instrumen Penilaian}

Bentuk-bentuk instrumen adalah sebagai berikut: 1) angket, 2) checklist, dan 3) rating scale. Bentuk checklist dan rating scale dapat digunakan sebagai pedoman observasi maupun wawancara (Sugiyono, 2010: 172). Adapun Instrumen yang digunakan dalam penelitian ini menggunakan instrumen observasi daftar cek (checklist).

\section{Teknik pengumpulan Data}

Teknik pengumpulan data adalah cara yang digunakan peneliti untuk mengumpulkan data (Suharsimi Arikunto, 2003: 134). Berbagai metode penelitian antara lain: angket, wawancara/interview, pengamatan, ujian atau tes, dokumentasi dan sebagainya. Teknik pengumpulan data (observasi ) dan wawancara

\section{Teknik Analisis data Data}

Pada penelitian ini, data yang dianalisis adalah hasil kegiatan pembelajaran mengenal huruf. Analisis pembelajaran anak dilakukan pada setiap pertemuan dalam siklus I dan II dengan menggunakan teknik diskriptif kuantitatif persentase. Adapun rumus yang digunakan dalam analisis data dengan teknik diskriptif kuantitatif persentase menurut Anas Sudijono (2010: 43) adalah sebagai berikut:

$\mathrm{f}$
$\mathrm{P}=---\mathrm{X} 100 \%$
$\mathrm{~N}$

Keterangan :

$$
\mathrm{F}=\text { Frekuensi yang sedang di cari persentasinya }
$$$$
\mathrm{N}=\text { Number of Cases (Jumlah frekuensi ) }
$$

$\mathrm{P}=$ Angka presentasi

Untuk mengetahui peningkatan kognitif pengenalan huruf anak dilakukan dengan 
membuat perbandingan skor yang di peroleh anak sebelum dan setelah pembelajaran dengan media kartu huruf.

Untuk mengetahui peningkatan kemampuan mengenal huruf anak dilakukan dengan membuat perbandingan persentase skor yang diperoleh anak sebelum dan setelah pembelajaran dengan media kartu kata.

Hasil data observasi tersebut dianalisis dan disesuaikan dengan kriteria yang diterapkan di taman kanak-kanak dengan pedoman sebagai berikut:

1. Kriteria 75\%-100\% Berkembang Sangat Baik (BSB).

2. Kriteria 50\%-74,99\% Berkembang Sesuai Harapan (BSH).

3. Kriteria 25\%-49,99\% Mulai Berkembang (MB).

4. Kriteria 0\%-24,99\% Belum Berkembang (BB).

\section{Indikator keberhasilan}

Kriteria keberhasilan dalam penelitian ini dianggap berhasil apabila ada peningkatan aktivitas siswa dalam mengikuti pembelajaran dan menunjukkan peningkatan pemahaman siswa dalam mengenal huruf dengan kriteria baik yaitu telah dapat menunjukkan huruf dengan benar, dapat menyebutkan simbol huruf dengan benar, dan dapat menghubungkan gambar dengan huruf dengan benar. Penelitian dianggap berhasil apabila sejumlah $75 \%$ dari anak kelompok B berkategori baik dalam mengenal huruf, dari
16 orang yang mengikuti ada sebanyak 12 anak yang dapat mengenal huruf.

\section{TEMUAN DAN PEMBAHASAN}

Temuan.

\section{Kondisi Awal}

Pada kondisi awal kemampuan anak dalam peningkatan kognitif pengenalan huruf di Kelompok B Kb Anggrek Muara Badak Tahun Ajaran 2015/2016 masih rendah. Hal ini dapat dilihat pada kondisi anak yang lebih suka bermain sendiri-sendiri, kurang antusias saat guru memberi pembelajaran tentang pengenalan huruf. Berdasarkan hasil penelitian awal, jumlah anak yang sudah mampu mencapai indikator keberhasilan dengan indikator Berkembang sangat Baik (BSB) belum ada, dari 16 anak didik hanya 2 siswa yang dapat mengerjakan tugas tanpa bantuan Guru, dengan indikator Berkembang Sesuai Harapan. sedangkan yang lain masih dibantu Guru, hal ini berarti kognitif siswa masih sangat rendah.

Berdasarkan hasil Observasi Kondisi pengenalan huruf awal Anak sebelum tindakan seperti diuraikan pada tabel di atas, diketahui terdapat 13 anak atau $81.25 \%$ dari total jumlah anak (16 anak) baru mampu mencapai indikator mulai berkembang pada variable Kemampuan menyebutkan huruf, 14 anak atau $87.5 \%$ dari total jumlah anak (16 anak) mampu mencapai indikator mulai berkembang pada variable Kemampuan menunjukkan huruf, Sedangkan Kemampuan untuk mengelompokkan huruf yang ada diketahui 
terdapat 12 anak (75 \%) dari total jumlah 16 anak baru mampu mencapai indikator mulai berkembang,dan dalam mengenal huruf dengan bunyi huruf ada 11 anak (68.75) dari total jumlah 16 anak baru mampu mencapai indikator mulai berkembang. Sedangkan nilai Rerata Ketuntasan kognitif Awal Anak sebelum tindakan dapat dilihat pada tabel 6 berikut ini:

Tabel 1. Rata- rata Ketuntasan awal anak

\begin{tabular}{|l|c|c|c|c|c|c|}
\hline \multicolumn{1}{|c|}{$\begin{array}{c}\text { Variable } \\
\text { yang } \\
\text { diobservasi }\end{array}$} & \multicolumn{3}{|c|}{ Hasil Pengamatan } & $\begin{array}{l}\text { Jumla } \\
\text { h yang } \\
\text { tuntas }\end{array}$ & \% \\
\cline { 2 - 6 } & BB & MB & $\begin{array}{l}\text { BS } \\
\text { H }\end{array}$ & $\begin{array}{l}\text { BS } \\
\text { B }\end{array}$ & & \\
\hline $\begin{array}{l}\text { Kemampuan } \\
\text { menyebutkan } \\
\text { huruf }\end{array}$ & 2 & 13 & 1 & 0 & $\mathbf{0}$ & $\mathbf{0}$ \\
\hline $\begin{array}{l}\text { Kemampuan } \\
\text { menunjukkan } \\
\text { huruf }\end{array}$ & 1 & 14 & 1 & 0 & $\mathbf{0}$ & $\mathbf{0}$ \\
\hline $\begin{array}{l}\text { Kemampuan } \\
\text { mengelompok } \\
\text { kan huruf }\end{array}$ & 2 & 12 & 2 & 0 & $\mathbf{0}$ & $\mathbf{0}$ \\
\hline $\begin{array}{l}\text { Mengenal } \\
\text { huruf dengan } \\
\text { bunyi huruf }\end{array}$ & 3 & 11 & 2 & $\mathbf{0}$ & $\mathbf{0}$ & $\mathbf{0}$ \\
\hline \multicolumn{7}{|c|}{ Rerata ketuntasan } \\
\hline
\end{tabular}

Dari tabel diatas dapat ditegaskan bahwa kemampuan kognitif pengenalan huruf anak belum terlatih dengan baik, di mana aspek di atas belum dapat dilakukan anak dengan maksimal atau kemampuan kognitif hanya mencapai satu indikator (mulai berkembang) dari empat indikator. Sedangkan indikator Berkembang Sangat Baik (BSB ) belum dicapai oleh anak dengan demikian rerata ketuntasan yang ditargetkan adalah $0.00 \%$. Keadaan ini menjadikan landasan untuk berupaya untuk mengembangkan kemampuan kognitif pengenalan huruf anak melalui media kartu huruf.

\section{Siklus I}

Pertemuan pertama pada siklus I dilaksanakan pada hari Kamis tanggal 10 September 2015. Pelaksanaan penelitian peningkatan kemampuan kognitif pengenalan huruf anak melalui media kartu huruf pada anak Kelompok B Kb Anggrek Muara Badak Tahun Ajaran 2015/2016 dilaksanakan dalam dua siklus. Masing-masing siklus terdiri dari 3 pertemuan dan dilaksanakan sesuai dengan tema pembelajaran.

Dari hasil kemampuan pengenalan huruf anak melalui media kartu huruf pada Sklus I,diketahui bahwa dalam aspek Kemampuan mengenal huruf, yaitu ada 6 anak (37.5\%) dari total jumlah anak (16 anak) yang mulai berkembang, anak yang berkembang sesuai harapan ada 4 anak (25\%), dan anak yang berkembang sangat baik ada 6 anak (37.5\%). Pada aspek Kemampuan menunjukkan huruf, yaitu anak yang mulai berkembang ada 4 anak (25\%), anak yang berkembang sesuai harapan ada5 anak (31,25\%), dan anak yang berkembang sangat baik ada 7 anak(43.75\%). Pada aspek Kemampuan mengelompokkan huruf, anak yang mulai berkembang ada 5anak $(31,25 \%)$, anak yang berkembang sesuai harapan ada 5 anak $(31,25 \%)$,dan anak yang berkembang sangat baik ada 7 anak (43.75\%).

Berdasarkan hasil rubrik perkembangan kemampuan mengenal huruf anak pada siklus I tersebut mengalami peningkatan dibandingkan dengan hasil Observasi Kondisi pengenalan huruf awal anak sebelum tindakan. 
Hal ini dapat dilihat dari tabel rerata ketuntasan kemampuan kreatifitas anak pada siklus I berikut ini:

Tabel 2. Rerata Ketuntasan pengenalan huruf awal pada

\begin{tabular}{|l|c|c|c|c|c|c|}
\hline \multicolumn{1}{|c|}{$\begin{array}{l}\text { Variable } \\
\text { yang } \\
\text { diobservasi }\end{array}$} & \multicolumn{3}{|c|}{ Hasil Pengamatan } & $\begin{array}{l}\text { Jumla } \\
\text { h yang } \\
\text { tuntas }\end{array}$ & \% \\
\cline { 2 - 6 } & $\begin{array}{l}\text { B } \\
\text { B }\end{array}$ & $\begin{array}{l}\text { M } \\
\text { B }\end{array}$ & $\begin{array}{l}\text { BS } \\
\text { H }\end{array}$ & $\begin{array}{l}\text { BS } \\
\text { B }\end{array}$ & & \\
\hline $\begin{array}{l}\text { Kemampuan } \\
\text { mengenal huruf }\end{array}$ & 0 & 6 & 4 & 6 & $\mathbf{6}$ & $\mathbf{3 7 . 5}$ \\
\hline $\begin{array}{l}\text { Kemampuan } \\
\text { menunjukkan } \\
\text { huruf }\end{array}$ & 0 & 4 & 5 & 7 & $\mathbf{7}$ & $\mathbf{4 3 . 7 5}$ \\
\hline $\begin{array}{l}\text { Kemampuan } \\
\text { mengelompokk } \\
\text { an huruf yang } \\
\text { sama }\end{array}$ & 0 & 5 & 5 & 6 & $\mathbf{6}$ & $\mathbf{3 7 . 5}$ \\
\hline $\begin{array}{l}\text { Mengenal huruf } \\
\text { dengan bunyi } \\
\text { huruf }\end{array}$ & 0 & 5 & 4 & 7 & $\mathbf{7}$ & $\mathbf{4 3 . 7 5}$ \\
\hline \multicolumn{7}{|c|}{ Rerata ketuntasan } \\
\hline
\end{tabular}

Dari tabel diatas diketahui bahwa

ketuntasan pengenalan huruf dengan media kartu huruf dengan kriteria nilai 4 yang dicapai anak Kelompok B Kb Anggrek Muara Badak Tahun Ajaran 2015/2016 memenuhi rerata peningkatan sebesar 40.63 persen dibandingkan dengan sebelum tindakan. Namun demikian peningkatan yang signifikan dari sebelum tindakan tersebut belum belum mencapai hasil yang diharapkan. Oleh karena itu kegiatan pengenalan huruf masih dilanjutkan pada tindakan siklus II.

\section{Refleksi}

Berdasarkan pelaksanaan siklus I, dari 16 anak didik yang sudah mencapai kemampuan maksimal atau berkembang sangat baik ada 6 anak. Dalam persentase ketercapaian anak dalam kemampuan kognitif pengenalan huruf anak melalui media kartu huruf pada Siklus Isebanyak 40,63\%. Dan anak yang masih dibimbing ada 10 orang atau 59,37\%. Ini adalah perkembangan yang baik dari sebelum dilakukan tindakan atau pada saat pra penelitian. Walaupun sudah menunjukkan perubahan yang meningkat namun masih dibutuhkan tindakan lagi pada siklus II supaya mencapai indikator keberhasilan. Dari tabel diatas ada 4 aspek kegiatan meningkatkan kemampuan kognitif pengenalan huruf anak yaitu Kemampuan mengenal huruf, Kemampuan menunjukkan huruf, Kemampuan mengelompokkan huruf yang sama dan mengenal huruf dengan bunyi huruf dengan rata-rata hasil sebagai berikut: Kemampuan mengenal huruf $37.5 \%$, Kemampuan menunjukkan huruf $43.75 \%$, Kemampuan mengelompokkan huruf yang sama $37.5 \%$, dan Mengenal huruf dengan bunyi huruf $43.75 \%$. Hasil pengamatan terhadap guru dalam mengajar tentang pengenalan huruf melalui media kartu huruf secara keseluruhan cukup baik. Guru sudah berusaha untuk menyampaikan materi . Guru selalu memberikan motivasi kepada siswa agar aktif dan bersemangat baik dengan tepuk atau dengan menyanyi. Guru juga telah 
memberikan penguatan yang positif kepada anak yang telah mencoba menggunakan media kartu huruf dengan benar sesuai aturan. Disamping itu Guru/ Peneliti mengajar dengan cara memberi tepuk tangan, memberikan pujian lisan sehingga anak merasa dihargai.

\section{Siklus II}

Pertemuan pertama pada siklus II dilaksanakan pada hari Kamis tanggal 17 September 2015. Diskusi dengan observer/ kolaborator tentang permasalahan baru yang timbul pada siklus I, hasil refleksi pada siklus I dijadikan dasar menyusun rencana perbaikan pembelajaran di RKH pada siklus II. Perencanaan tindakan pada Siklus II ini pada dasarnya samadengan perencanaan tindakan pada Siklus I. Namun ada tindakan tambahan pada siklus II ini, yakni memberikan solusi terhadap siswa yang hasil belajarnya masih Mulai berkembang (MB) dan berkembang sesuai harapan (BSH) agar meningkat kriterianya menjadi berkembang sangat baik (BSB).

Dari hasil kemampuan Kognitif pengenalan huruf anak melalui media kartu huruf pada Sklus II, diketahui bahwa dalam aspek Kemampuan mengenal huruf, yaitu ada 4 anak (25\%) dari total jumlah anak (16 anak) berkembang sesuai harapan (BSH), dan anak yang berkembang sangat baik ada 12 anak (75\%). Pada aspek Kemampuan menunjukkan huruf, anak yang berkembang sesuai harapan (BSH) ada 3 anak (18.75\%)dari total jumlah anak (16 anak), dan anak yang berkembang sangat baik ada 13 anak (81.25\%)dari total jumlah anak (16 anak). Pada aspek Kemampuan mengelompokkan huruf, ada 3 anak (18.75\%) dari total jumlah anak (16 anak)yang berkembang sesuai harapan $(\mathrm{BSH})$, dan anak yang berkembang sangat baik (BSB) ada 13 anak (81.25\%) dari total jumlah anak (16 anak).

Berdasarkan hasil rubrik perkembangan kemampuan kognitif anak anak pada siklus II tersebut, dapat disimpulkan bahwa pengenalan huruf anak mengalami peningkatan dibandingkan dengan hasil pengenalan huruf anak pada siklus I. Hal ini dapat dilihat dari tabel rerata ketuntasan kemampuan pengenalan huruf anak pada siklus II berikut ini:

Tabel 3. Rerata Ketuntasan kreatifitas anak pada Siklus

\begin{tabular}{|c|c|c|c|c|c|c|}
\hline \multirow{2}{*}{$\begin{array}{c}\text { Variable } \\
\text { yang } \\
\text { diobservasi }\end{array}$} & \multicolumn{4}{|c|}{ Hasil Pengamatan } & \multirow{2}{*}{$\begin{array}{l}\text { Jumla } \\
\text { h } \\
\text { yang } \\
\text { tuntas }\end{array}$} & \multirow{2}{*}{$\%$} \\
\hline & $\begin{array}{l}\text { B } \\
\text { B }\end{array}$ & $\begin{array}{l}\mathrm{M} \\
\mathrm{B}\end{array}$ & $\begin{array}{l}\text { BS } \\
\mathrm{H}\end{array}$ & $\begin{array}{l}\text { BS } \\
\text { B }\end{array}$ & & \\
\hline $\begin{array}{l}\text { Kemampuan } \\
\text { mengenal } \\
\text { huruf }\end{array}$ & 0 & 0 & 4 & 12 & 12 & 75 \\
\hline $\begin{array}{l}\text { Kemampuan } \\
\text { menunjukkan } \\
\text { huruf }\end{array}$ & 0 & 0 & 3 & 13 & 13 & 81.25 \\
\hline $\begin{array}{l}\text { Kemampuan } \\
\text { mengelompok } \\
\text { kan huruf } \\
\text { yang sama }\end{array}$ & 0 & 0 & 3 & 13 & 13 & 81.25 \\
\hline $\begin{array}{l}\text { Mengenal } \\
\text { huruf dengan } \\
\text { bunyi huruf }\end{array}$ & 0 & 0 & 3 & 13 & 13 & 81.25 \\
\hline \multicolumn{6}{|c|}{ Rerata ketuntasan } & 79.67 \\
\hline
\end{tabular}

Dari tabel diatas diketahui bahwa

ketuntasan pengenalan huruf anak melalui media kartu huruf yang dicapai anak Kelompok B Kb Anggrek Muara Badak Tahun Ajaran 2015/2016dengan kriteria nilai 
4 (BSH) menjadi 79.67 persen pada siklus II. Hal ini meningkat dari rerata ketuntasan pengenalan huruf anak melalui media kartu huruf pada siklus I yaitu 40.63 persen. Terdapat peningkatan kognitif anak yang signifikan pada siklus II dibandingkan dengan kognitif anak pada siklus I.Berdasarkan data persentase di atas peneliti dapat menyimpulkan bahwa rerata ketuntasan kognitif anak pada siklus II telah mencapai hasil yang diharapkan.

\section{Pembahasan Hasil Penelitian}

Pelaksanaan kegiatan kognitif pengenalan huruf anak melalui media kartu huruf yang dicapai anak Kelompok B Kb Anggrek Muara Badak Tahun Ajaran 2015/2016 dilaksanakan dalam dua siklus dan masing-masing siklus dilaksanakan dalam tiga kali pertemuan. Untuk mengetahui kemampuan kognitif pengenalan huruf anak kelompok B, maka peneliti mengadakan kegiatan pra tindakan. Kemampuan kreatifitas anak sebelum tindakan dapat dikatakan belum tuntas dengan indek rerata ketuntasan $0.00 \%$. Hal ditunjukkan dari hasil hasil Observasi Kondisi kognitif pengenalan huruf Awal Anak sebelum tindakan diketahui terdapat 13 anak atau $81.25 \%$ dari total jumlah anak (16 anak) baru mampu mencapai indikator mulai berkembang pada variable Kemampuan mengenal huruf, 14 anak atau $87.5 \%$ dari total jumlah anak (16 anak) mampu mencapai indikator mulai berkembang pada variable Kemampuan menunjukkan huruf, Sedangkan Kemampuan mengelompompokkan huruf yang sama diketahui terdapat 12 anak (75\%) dari total jumlah 16 anak baru mampu mencapai indikator mulai berkembang,Sedangkan indikator Berkembang Sangat Baik (BSB ) belum dicapai oleh anak dengan demikian rerata ketuntasan yang ditargetkan adalah $0.00 \%$.

Kemampuan kognitif pengenalan huruf Anak pada siklus I dapat dikatakan meningkat dengan indek rerata ketuntasan 40.63\%. Diketahui bahwa dalam aspek kemampuan mengenal huruf, yaitu ada 6 anak (37.5\%) dari total jumlah anak (16 anak) yang mulai berkembang, anak yang berkembang sesuai harapan ada 4 anak (25\%), dan anak yang berkembang sangat baik ada 6 anak (37.5\%). Pada aspek Kemampuan menunjukkan huruf, yaitu anak yang mulai berkembang ada 4 anak (25\%), anak yang berkembang sesuai harapan ada 5 anak $(31,25 \%)$, dan anak yang berkembang sangat baik ada 7 anak (43.75\%). Pada aspek Kemampuan mengelompokkan huruf yang sama, anak yang mulai berkembang ada 5 anak $(31,25 \%)$, anak yang berkembang sesuai harapan ada 5 anak $(31,25 \%)$, dan anak yang berkembang sangat baik ada 6 anak (37.5\%). Sedangkan pada mengenal huruf dengan bunyi huruf,anak yang mulai berkembang ada 5 anak $(31,25 \%)$, anak yang berkembang sesuai harapan ada 4 anak $(25 \%)$, dan anak yang berkembang sangat baik ada 7 anak (43.75\%). 
Pengembangan kemampuan kognitif pengenalan huruf anak yang dicapai pada siklus I,belum mencapai keberhasilan yang ditetapkan, disebabkan oleh beberapakendala yang muncul pada pelaksanaan tindakan siklus I antara lain : (1) penguasaan materi oleh guru/peneliti dalam mengenalkan bermain kartu huruf pada kegiatan mengenal huruf masih kurang, (2) Penjelasan guru/peneliti terlalu cepat, (3) Keaktifan anak masih kurang, dan (4) Bentuk kurang bervariasi,sehingga anak mulai terasa jenuh dan terlihat bosan pada akhir pertemuan pada siklus I.

Perbaikan yang dilakukan terhadap kendala yang muncul pada siklus I, menghasilkan peningkatan yang signifikan terhadap kemampuan kognitif pengenalan huruf anak yang dicapai anak kelompok B pada tindakan siklus II. Hal ini ditunjukkan dari hasil yang dicapai dengan tingkat rerata ketuntasan meningkat menjadi $79.67 \%$ dari siklus I yaitu 40.63\%.Diketahui bahwa dalam aspek Kemampuan mengenal huruf naik menjadi ada 4 anak (25\%) dari total jumlah anak (16 anak) anak berkembang sesuai harapan dan anak yang berkembang sangat baik ada 12 anak (75\%). Pada aspek Kemampuan menunjukkan huruf, anak yang berkembang sesuai harapan ada 3 anak (18.75\%), dan anak yang berkembang sangat baik ada 13 anak (81.25\%). Pada aspek Kemampuan mengelompokan huruf yang sama, anak yang berkembang sesuai harapan ada 3 anak (18.75\%), dan anak yang berkembang sangat baik ada 13 anak (81.25\%). Sedangkan pada mengenal huruf dengan bunyi huruf, anak yang berkembang sesuai harapan ada 3 anak (18.25\%), dan anak yang berkembang sangat baik ada 13 anak $(81.25 \%)$.

Prosentase kemampuan anak dalam mengikuti kegiatan dari mulai studi awal sampai pelaksanaan perbaikan pembelajaran pada siklus I dan siklus II dapat dilihat pada tabel 8 sebagai berikut :

Tabel 3: Rerata Ketuntasan kreatifitas anak pada kondisi

\begin{tabular}{|l|c|c|c|}
\hline \multicolumn{1}{|c}{$\begin{array}{c}\text { Variable } \\
\text { yang } \\
\text { diobservasi }\end{array}$} & \multicolumn{3}{|c|}{ Rerata ketuntasan } \\
\cline { 2 - 4 } & $\begin{array}{l}\text { Kondisi } \\
\text { awal }\end{array}$ & Siklus I & Siklus II \\
\hline $\begin{array}{l}\text { Kemampuan } \\
\text { mengenal } \\
\text { huruf }\end{array}$ & $0.00 \%$ & $37.55 \%$ & $75 \%$ \\
\hline $\begin{array}{l}\text { Kemampuan } \\
\text { menunjukka } \\
\text { nuruf }\end{array}$ & $0.00 \%$ & $43.75 \%$ & $81.25 \%$ \\
\hline $\begin{array}{l}\text { Kemampuan } \\
\text { mengelompo } \\
\text { kkan huruf } \\
\text { yang sama }\end{array}$ & $0.00 \%$ & $37.5 \%$ & $81.25 \%$ \\
\hline $\begin{array}{l}\text { Mengenal } \\
\text { huruf dan } \\
\text { bunyi huruf }\end{array}$ & $0.00 \%$ & $43.75 \%$ & $81.25 \%$ \\
\hline Rerata & $0.00 \%$ & $40.63 \%$ & $79.67 \%$ \\
\hline
\end{tabular}

Berdasarkan pembahasan hasil kegiatan peningkatan kemampuan kognitif anak melalui media kartu huruf pada siklus I dan siklus II di atas, maka kemampuan kognitif pengenalan huruf anak kelompok $\mathrm{B}$ di $\mathrm{Kb}$ Anggrek Muara Badak Tahun Ajaran 2015/2016 mengalami peningkatan dapat dikatakan meningkat dengan baik. Selain hasilyang dicapai, keberhasilan yang lain juga dapat dilihat pada semangat dan antusias anakanak selama kegiatan berlangsung. Hal ini 
juga menunjukkanbahwa proses kegiatan seperti ini sesuai dengan yang dikehendaki dan direncanakan oleh peneliti, yaitu anakanak mau melakukan kegiatan tanpa ada paksaan maupun tekanan. Selain dari indikator tersebut diatas, hasil persentase keberhasilan dengan kreteria Berkembang Sangat Baik (BSB) mencapai $79.67 \%$ atau 12 anak dari 16 anak.

Pada intinya anak menyukai suasana kegiatan dengan variasi pembelajaran yang dilakukan, sehingga memunculkan hal-hal ataupun tantangan yang baru. Untuk itu kegiatan kreatifitas anak harus dikembangkan dan diperkaya dengan inovasi-inovasi yang baru, agar dapatmemotivasi dan menarik anak untuk melakukannya. Melalui media kartu huruf ini mampu mengembangkan kemampuan kognitif pengenalan huruk anak.Hal ini sesuai dengan pendapat Suratno, (2005:10) , Anak Kreatif yaitu anak yang mampu memperdayakan pikirannya untuk menghasilkan gagasan baru, memecahkan masalah dan ide yang mempunyai maksud dan tujuan yang di tentukan. Ketika anak mengekspresikan pikirannya atau kegiatannya yang berdaya cipta, berinisiatif sendiri, dengan cara-cara yang original, maka kita dapat mengatakan bahwa mereka itu adalah anak yang kreatif.

Hasil persentase keberhasilan dengan kreteria Berkembang Sangat Baik (BSB) pada kemampuan mengenal huruf anak melalui metode bermain kartu huruf mencapai 79.67
$\%$ atau 12 anak dari 16 anak. Perbaikan yang dilakukan terhadap kendala yang muncul pada siklus I, menghasilkan peningkatan yang signifikan terhadap kemampuan mengenal huruf anak yang dicapai anak kelompok B pada tindakan siklus II. Hal ini ditunjukkan dari hasil yang dicapai dengan tingkat rerata ketuntasan meningkat menjadi $79.67 \%$ dari siklus I yaitu $40.63 \%$ dimana pada observasi sebelum tindakan, kemampuan mengenal huruf anak kelompok B di Kb Anggrek Muara Badak Tahun Ajaran 2015/2016 mempunyai rerata ketuntasan $0,00 \%$. Mengidentifikasikan bahwa pembelajaran melalui media kartu huruf dapat meningkatkan kemampuan kognitif pengenalan huruf anak pada anak kelompok Bdi Kb Anggrek Muara Badak Tahun Ajaran 2015/2016. Oleh karena itulah dianjurkan kepada guru Pendidikan Anak Usia Dini untuk menggunakan media kartu huruf dalam meningkatkan kemampuan kognitif pengenalan huruf anak di Pendidikan Anak Usia Dini.

\section{Kesimpulan}

1. Pembelajaran melalui media kartu huruf dapat meningkatkan kemampuan kognitif anak pada anak kelompok $\mathrm{B}$ di $\mathrm{Kb}$ Anggrek Muara Badak Tahun Ajaran 2015/2016. Hal ini ditunjukkan oleh rerata ketuntasan pencapaian kemampuan kognitif pengenalan huruf anak pada sebelum tindakan adalah $0.00 \%$ menjadi $40.63 \%$ pada siklus 1 dan setelah beberapa 
perbaikan pada siklus II mencapai $79.67 \%$

2. Langkah-langkah pembelajaran guru dalam mengajar dengan melalui metode Bermain Karu huruf secara keseluruhan sangat baik. Guru sudah berusaha untuk menyampaikan materi dengan baik. Guru selalu memberikan motivasi kepada siswa agar aktif dan bersemangat baik dengan tepuk atau dengan menyanyi. Guru juga telah memberikan penguatan yang positif kepada anak yang telah mencoba menggunakan media kartu huruf dengan benar sesuai aturan. Disamping itu Guru/ Peneliti mengajar dengan cara memberi tepuk tangan, memberikan pujian lisan sehingga anak termotivasi dan merasa dihargai.

\section{Saran}

1. Bagi anak, agar anak memiliki kemampuan mengenal huruf dengan baik, anak lebih muda membedakan huruf, anak mampu memiliki dan mengelompokan warna/huruf.

2. Bagi guru, Agar dapat menggunakan media pembelajaran dengan bantuan kartu huruf A-Z ini untuk peningkatan kemampuan belajar mengenal huruf anak usia dini khususnya KB.ANGGREK kecamatan muara badak kabupaten kutai kartanegara .

\section{DAFTAR PUSTAKA}

Amin Suyitno. 2005 .semarang.petunjuk praktis penelitian tindakan kelas untuk penyusunan skripsi.

Anderson. R.C.1972. language sekills in elementary education. New york: macmillan publishing $\mathrm{Co}$, inc.

Beck,j. 1994. Meningkatkan kecerdasan anak. Jakarta:pustaka.

Anas Sudjono,2010. Pengantar Statistik pendidikan. Jakarta PT.raja grafindo persada

Family 07-04-2011, writing com/ opini/, belajar membaca untuk anak usia dini. Html 2009.

Fationip, (2009). Pengembangan kemampuan membaca anak usia dini melalui metode glenn doman. www.fatonipgsd071644221.wordpress .com

Gardner, H.(2000).multipl intelegences Teori dan praktek (terjemah).Bata.Interaksa.

Hadi, sutrisno (1987).metodologi research jilid I.Yogyakarta.fakultas pesikolokgi UGM.

Hadi, Sutrisno (1991).metodologi research cetakan ketuju. Jogjakarta. Fakultas pesikologi UGM.

I wayan santyasa,(2007), makalah metodologi penelitian tindakan kelas.singaraja, universitas pendidikan ganesha.

Kenny Dewi Juwita, (1998) .menciptakan bahaya ajaran yang berpusat pada anak, Jakarta, penerbit Children's Resources Intertional,INC.

Muchim Suagiono,(1996).Unipress IKIP, media pendidikan dan ilmu pengetahuan Surabaya. 
Nurbiana Dhieni dkk, (2005).Jakarta, metode pengembangan bahasa, penerbit unifersitasa terbuka.

Persiapan membaca anak TK,(2007): departemen pendidikan nasional direktorat jendral.

Suharsimi Arikunto, suharjono, (2006).penelitian tindakan kelas,Jakarta.PT.B umi aksara.

Tim PKM PGTK,(2009),Jakarta,konsep dasar $P K M$,unifersitas terbuka.

Yuliana Nurani Sujiono, (2004). Jakarta, metode pengembangan kognitif penerbit unifersitas terbuka.

Zainal Aqib.(2009),bandung.PTK Untuk Guru $S D, S L B$, dan

TK.CV.Yramn widya.

Zaman,B.(2005). Jakarta, media dan sumber belajar $T K$, penerbit

universitas terbuka.

Suharsimi Arikunto. (2006). Penelitian Tindakan Kelas. Yogyakarta: Aditya Media. 
